\title{
The role of temperate treed swamps as a carbon sink in southwestern Nova Scotia ${ }^{1}$
}

\author{
Rachel A. Kendall, Karen A. Harper, David Burton, and Kevin Hamdan
}

\begin{abstract}
Forested wetlands may represent important ecosystems for mitigating climate change effects through carbon (C) sequestration because of their slow decomposition and C storage by trees. Despite this potential importance, few studies have acknowledged the role of temperate treed swamps in the C cycle. In southwestern Nova Scotia, Canada, we examined the role of treed swamps in the soil $\mathrm{C}$ cycle by determining $\mathrm{C}$ inputs through litterfall, assessing decomposition rates and soil C pools, and quantifying C outputs through soil greenhouse gas (GHG) emissions. The treed swamps were found to represent large supplies of $C$ inputs through litterfall to the forest floor. The swamp soils had substantially greater $C$ stores than the swamp-upland edge or upland soils. We found growing season C inputs via litterfall to exceed C outputs via GHG emissions in the swamps by a factor of about 2.5. Our findings indicate that temperate treed swamps can remain a $\mathrm{C}$ sink even if soil GHG emissions were to double, supporting conservation efforts to preserve temperate treed swamps as a measure to mitigate climate change.
\end{abstract}

Key words: forested wetland, treed swamp, carbon sink, carbon sequestration, greenhouse gas flux.

Résumé : Les milieux humides boisés pourraient s'avérer d'importants écosystèmes pour atténuer les effets du changement climatique en séquestrant du carbone $(C)$ à cause de la lenteur de la décomposition et du stockage de $C$ dans les arbres. Malgré cette importance potentielle, peu d'études ont reconnu le rôle des marécages arborescents en zone tempérée dans le cycle du C. Dans le sud-ouest de la Nouvelle-Écosse, au Canada, nous avons étudié le rôle des marécages arborescents dans le cycle du $\mathrm{C}$ dans le sol en déterminant les apports de $\mathrm{C}$ provenant de la chute de litière, en évaluant les taux de décomposition et les réservoirs de $C$ dans le sol, et en quantifiant la production de $C$ par l'entremise des émissions de gaz à effet de serre (GES) en provenance du sol. Nous avons observé que les marécages arborescents fournissaient d'importantes quantités d'apports de $C$ dans la couverture morte par l'entremise de la chute de litière. Les sols des marécages emmagasinaient substantiellement plus de $\mathrm{C}$ que les sols situés à la limite entre les marécages et les terres hautes ou ceux des terres hautes. Nous avons observé que les apports de C durant la saison de croissance par l'entremise de la chute de litière excédaient la production de $\mathrm{C}$ due aux émissions de GES dans les marécages par un facteur d'environ 2,5. Nos résultats indiquent que les marais arborescents en zone tempérée peuvent demeurer un puits de C même si les émissions de GES du sol devaient doubler, ce qui supporte les efforts de conservation visant à préserver les marécages arborescents en zone tempérée comme mesure d'atténuation du changement climatique. [Traduit par la Rédaction]

Mots-clés : milieu humide boisé, marécage arborescent, puits de carbone, séquestration du carbone, flux de gaz à effet de serre.

\section{Introduction}

Wetlands may be key ecosystems for mitigating the effects of fossil fuel emissions on climate through carbon (C) sequestration (Mitsch and Hernandez 2013). Although they cover only a small fraction of Earth's terrestrial surface, wetlands store a large proportion (20\%-30\%) of Earth's C (Lal 2008). Wetlands can have large $\mathrm{C}$ stores and high $\mathrm{C}$ sequestration rates if net primary productivity exceeds decomposition over long time scales (Gorham 1991; Whiting and Chanton 2001). Although soil organic matter accounts for the largest amount of total $\mathrm{C}$ (more than three times as much $\mathrm{C}$ as the atmosphere and vegetation; Schmidt et al. 2011), rising global air temperatures and increasing soil temperatures may lead to increased rates of respiration and greenhouse gas (GHG) production from the soil.

Higher temperatures can increase carbon dioxide $\left(\mathrm{CO}_{2}\right)$ and methane $\left(\mathrm{CH}_{4}\right)$ production by increasing microbial activity in wetlands (Hogg et al. 1992); soil moisture content also regulates $\mathrm{CO}_{2}$ and $\mathrm{CH}_{4}$ production and is an important controlling factor of biogeochemical processes in wetlands (Trettin and Jurgensen 2002). With climate models showing long-term warming trends (Hartmann et al. 2013), wetlands may have potential for large $\mathrm{CO}_{2}$ and $\mathrm{CH}_{4}$ fluxes to the atmosphere if wetland $\mathrm{C}$ stores are destabilized by global warming (Limpens

Received 14 September 2019. Accepted 29 October 2020.

R.A. Kendall*. Department of Geography and Environmental Studies, Saint Mary’s University, 923 Robie Street, Halifax, NS B3H 3C3, Canada.

K.A. Harper. School for Resource and Environmental Studies, Dalhousie University, 6100 University Avenue, Suite 5010, Halifax, NS B3H 4R2, Canada.

D. Burton. Department of Plant, Food, and Environmental Sciences, Dalhousie University, 21 Cox Road, Truro, NS B2N 5E3, Canada.

K. Hamdan. Department of Geography and Environmental Studies, Carleton University, 1125 Colonel By Drive, Ottawa, ON K1S 5B6, Canada.

Corresponding author: Kevin Hamdan (email: kevin.hamdan@carleton.ca).

*Present address: Department of Geography, McGill University, 805, rue Sherbrooke Ouest, Montreal, QC H3A 0B9, Canada.

${ }^{1}$ This article is part of a virtual collection entitled "Biodiversity and ecosystem functioning of forested wetlands across Atlantic Canada".

Copyright remains with the author(s) or their institution(s). Permission for reuse (free in most cases) can be obtained from copyright.com. 
et al. 2008) or affected by other disturbances such as drainage (Moomaw et al. 2018).

The cycling of $\mathrm{C}$ in wetlands is determined by $\mathrm{C}$ inputs as litterfall and belowground biomass and $\mathrm{C}$ outputs as $\mathrm{CO}_{2}$ from plant respiration and both aerobic and anaerobic decomposition, $\mathrm{CH}_{4}$ from anaerobic decomposition, and dissolved organic $\mathrm{C}$ (DOC). Above- and belowground biomass production represents the largest source of soil C in wetlands (Trettin and Jurgensen 2002). Dissolved organic matter, which is comprised of a broad spectrum of organic compounds that includes DOC, represents approximately $<1 \%$ of total soil organic matter in wetlands (Reddy and DeLaune 2008). Carbon sequestration rates vary for wetlands depending on wetland type and climate, with ranges of 2-46 $\mathrm{g} \mathrm{C} \cdot \mathrm{m}^{-2} \cdot \mathrm{year}^{-1}$ in northern peatlands, 64-240 $\mathrm{g} \mathrm{C} \cdot \mathrm{m}^{-2} \cdot$ year $^{-1}$ in coastal wetlands, 83$387 \mathrm{~g} \mathrm{C}^{-2} \mathrm{~m}^{-2} \cdot$ year $^{-1}$ in temperate wetlands, and $42-480 \mathrm{~g} \mathrm{C} \cdot \mathrm{m}^{-2} \cdot$ year $^{-1}$ in tropical wetlands (Mitsch et al. 2013).

In Canada, forested wetlands include treed and shrub swamps, as well as treed fens and bogs (National Wetlands Working Group 1997). Treed swamps are distinguished by trees, shrubs, and forbs, with $>30 \%$ canopy cover. Carbon storage and cycling had been largely studied in treed fens and bogs. Bhatti et al. (2006) found $C$ stocks to increase along a gradient from uplands to forested peatlands, and Flanagan and Syed (2011) found forested peatland ecosystems to have a C balance of $43 \pm 12 \mathrm{~g} \mathrm{C} \cdot \mathrm{m}^{-2} \cdot \mathrm{year}^{-1}$. A few studies have acknowledged the role of northern temperate treed swamps in the $C$ cycle, but none have examined all in situ parameters of GHG emissions, litterfall, litter decomposition, and soil C. Middleton (2020) measured C stocks and litter decomposition of forested swamps, Miao et al. (2017) measured respiration at ecosystem scale, and Trettin and Jurgensen (2002) compiled C component measurements of some treed swamps.

Treed swamps are distinguished from open wetlands by the presence of an adequate aeration zone above the water table available for root growth of tall trees and shrubs (National Wetlands Working Group 1997). Carbon cycle dynamics of treed swamps may vary, however, by tree growth form, with evergreen forests accumulating greater forest floor litter masses than deciduous forests (Vogt et al. 1986). Along with a tree overstory, treed swamps may also have large understory biomass (Campbell 2000), both providing an input source of $\mathrm{C}$. However, the understory productivity may be less comparable to that of open wetlands because of light interception by trees (McCrady and Jokela 1998).

The goal of our research was to quantify the $C$ balance of treed swamps of southwestern Nova Scotia, Canada. Specifically, we aimed to determine whether treed swamp soils are a net $C$ sink or $C$ source in relation to climate change. Our specific objectives were to determine the $\mathrm{C}$ input to the soil through litterfall; assess the decomposition rate and soil $\mathrm{C}$ pools; quantify the soil $\mathrm{C}$ outputs as $\mathrm{CO}_{2}$ and $\mathrm{CH}_{4}$, and nitrous oxide $\left(\mathrm{N}_{2} \mathrm{O}\right)$ as a $\mathrm{CO}_{2}$ equivalent (non- $\mathrm{CO}_{2}$ emissions converted to $\mathrm{CO}_{2}$ equivalents via their sustained global warming potentials as described by Neubauer and Megonigal 2015); and compare these variables among the soil of treed swamp, upland forest, and the forest edge between the two ecosystems. Assessing soil $\mathrm{C}$ inputs and outputs will contribute to our understanding of soil $\mathrm{C}$ cycling components and the ecological role (i.e., C sink or source) of the soil of temperate treed swamp ecosystems.

\section{Materials and methods}

\section{Study area and sampling design}

The study area was located in southwestern Nova Scotia (Fig. 1). We chose three sites: two located within the Katewe'katik Wilderness Area, Queens County, at different wetlands (site 1: $44^{\circ} 26^{\prime} 02.2^{\prime \prime} \mathrm{N}, 65^{\circ} 04^{\prime} 49.4^{\prime \prime} \mathrm{W}$; site 2 : $44^{\circ} 26^{\prime} 05.7^{\prime \prime} \mathrm{N}, 65^{\circ} 04^{\prime} 47.2^{\prime \prime} \mathrm{W}$; approximately $120 \mathrm{~m}$ apart) and one within Kejimkujik National Park and National Historic Site (site 3: $44^{\circ} 23^{\prime} 16.6^{\prime \prime} \mathrm{N}, 65^{\circ} 12^{\prime} 26.4^{\prime \prime} \mathrm{W}$ ). We selected the study sites (Fig. 1) using satellite images and field data obtained from pilot studies. Each site was differentiated by dominant species and vegetation composition and structure.

The study area lies within the LaHave Drumlins Ecodistrict of the Western Ecoregion (Neily et al. 2017) and the Acadian Forest Region (Rowe 1972). The ecodistrict is characterized by shallow, stony glacial till derived from the underlying dominant slate and deeper, less stony till in the form of drumlins (Neily et al. 2005). The forest stands of sites 1 and 2 are 40-80 years old, and the forest stand of site 3 is $85-150$ years old (Nova Scotia Department of Lands and Forestry 2013).

The forested wetlands of our sites had $>30 \%$ canopy cover and wood-rich peat 9-30 cm thick, meeting the definition of treed swamps according to the Canadian Wetland Classification System (National Wetlands Working Group 1997). The treed swamps at each site had no apparent surface water connection to streams for water supply, but rather were occasionally flooded during the year with drier periods in the summer. Adjacent upland forests were located at higher elevation than the swamps and had moderate soil drainage and aeration. During 2017, the year in which field sampling for our study took place, the total precipitation was $76.9 \mathrm{~mm}$ in January and $63.1 \mathrm{~mm}$ in July, and mean temperature was $-2.5^{\circ} \mathrm{C}$ in January and $19.0^{\circ} \mathrm{C}$ in July (Government of Canada 2017).

Site 1 was a treed swamp and mixedwood upland dominated by Tsuga canadensis (L.) Carrière, site 2 was an Acer rubrum L. treed swamp and a mixedwood upland dominated mainly by species of Picea A. Dietr. and Betula populifolia Marshall, and site 3 was a Picea spp. treed swamp and a mixedwood upland dominated by Abies balsamea (L.) Mill. (Table 1). The understory of the uplands was dominated by bryophyte species, whereas the understory of the swamps was dominated by a combination of bryophytes, herbs, graminoids, and shrubs (Table 1). The edge between the swamps and uplands was dominated mainly by species of Sphagnum L.

We collected data within three $20 \mathrm{~m} \times 5 \mathrm{~m}$ sampling plots at each site along a transect in the treed swamp, in the upland forest, and at the edge between the treed swamp and upland forest. The treed swamp plots were $20-60 \mathrm{~m}$ from the edge plots, and the upland forest plots were $40-60 \mathrm{~m}$ from the edge plots (Table 1). The treed swamp and upland plots in each site were selected within $60 \mathrm{~m}$ from the edge based on similarity in species composition, dominant species, and canopy cover. The minimum distance between treed swamp and upland plots within a site was $60 \mathrm{~m}$.

\section{Litterfall sampling and analysis}

To collect litterfall, we used plastic trays $(24 \mathrm{~cm} \times 50.5 \mathrm{~cm})$ lined with fiberglass mesh (pore size of $3 \mathrm{~mm}^{2}$ ) with holes created on the bottom of the trays to allow for water drainage. We randomly placed four trays within 2.5 and $10 \mathrm{~m}$ from the centre of each plot in each of the four cardinal directions. Litterfall and mesh lining were collected and combined per plot for all subsequent analyses. After collecting the litterfall and mesh, we placed new mesh in the trays for subsequent collection. We collected litterfall from May to December 2017 on a monthly basis during spring (May-June) and summer (July-September) and once every 2 weeks during autumn (October-December). Litterfall in temperate mixed-forest ecosystems follows a bimodal trend with peaks in autumn and spring (Zhang et al. 2014), with most occurring in autumn (Sabau et al. 2010). Litterfall was not collected during the winter season because of difficulty accessing the study sites.

We air-dried litter samples for a minimum of $24 \mathrm{~h}$ and then carefully removed them from the mesh and combined the four samples per plot for oven-drying. The air-dried samples were weighed, oven-dried for $24 \mathrm{~h}$ at $70^{\circ} \mathrm{C}$, and reweighed. Leaves and needles were then separated from twigs and other material to determine the mass of the leaf and needle litterfall.

After oven-drying, litterfall samples were ground in a coffee grinder in preparation for total $\mathrm{C}$ and total nitrogen $(\mathrm{N})$ analysis. 
Fig. 1. Location of study sites in southwestern Nova Scotia. Map projection: NAD83(CSRS) / UTM zone 20N, Transverse Mercator. Map was created using ArcGIS version 10.6 (Esri, Redlands, Calif., USA) and was assembled from the following sources: Atlas of Canada (1:2 000 000): Natural Resources Canada, 2009; delimiter lines and water features: Nova Scotia Topographic Database, 2015; and existing and pending parks and protected areas: Esri, 2017.

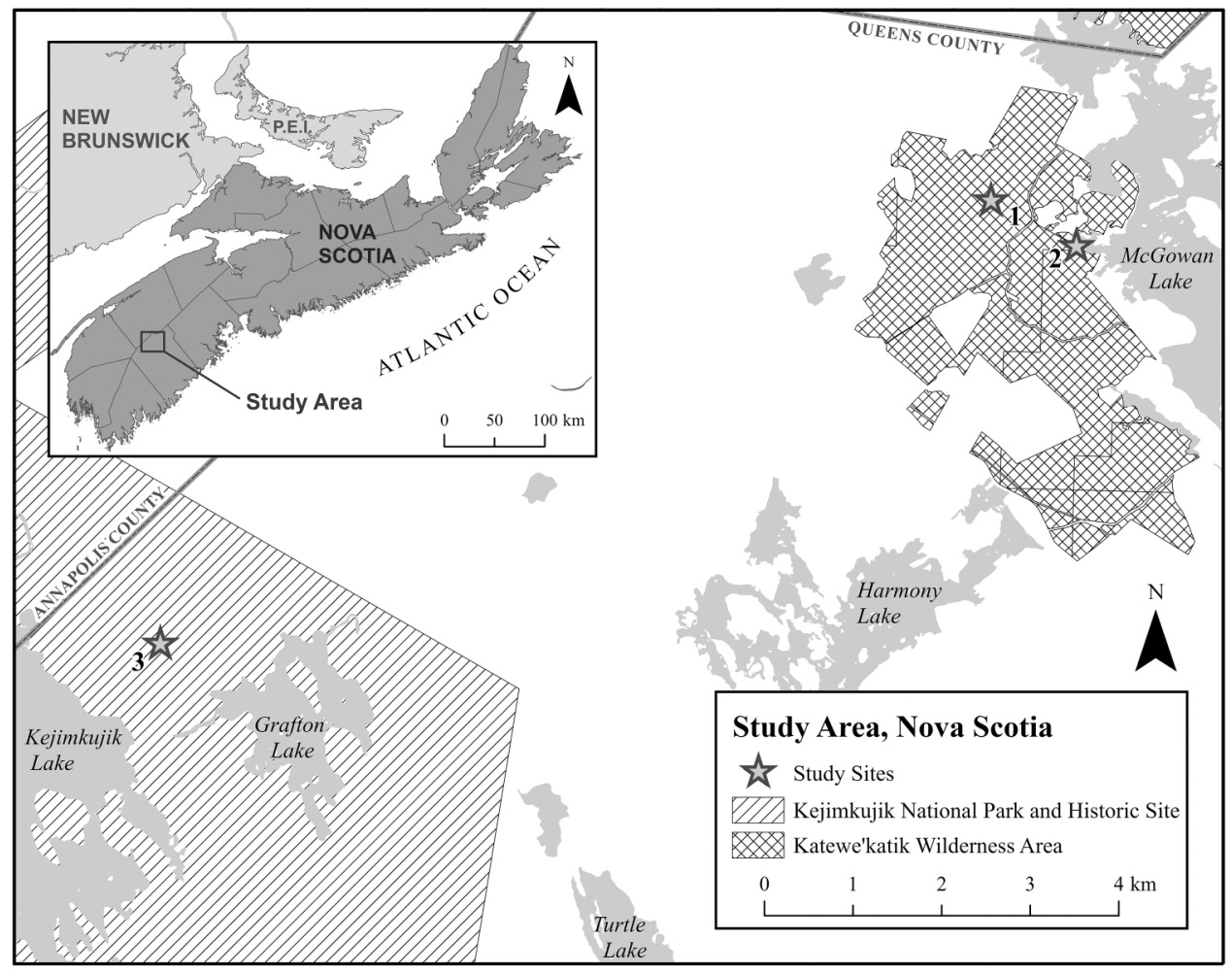

We sent subsamples of approximately $2 \mathrm{~g}$ from each season to the British Columbia Ministry of Environment Analytical Laboratory for elemental analysis. Total $\mathrm{C}$ and total $\mathrm{N}$ were determined by grinding tissue samples with a Wiley mill (produced by Thomas Scientific) and running them through a Fisons NA1500 elemental analyzer. Concentrations of $C$ and $\mathrm{N}$ were used to calculate the C:N ratio of the litterfall.

\section{Litter decomposition analysis}

We used tea bags to measure the relative decomposition rates among plots following the Tea Bag Index (TBI) procedure (Keuskamp et al. 2013), an approach that uses standardized plant litter (tea) to measure decomposition and stabilization. We buried Lipton green tea (EAN 871090890359 5) and Lipton rooibos tea (EAN 8722700188438 ) in four pairs at each sampling plot on 23 May 2017. Before burying the tea bags, we determined the initial mass of the tea and the mesh bags.

We buried each pair of tea bags in $5 \mathrm{~cm}$ wide holes at a depth of $8 \mathrm{~cm}$ approximately $0.5-1 \mathrm{~m}$ from the litter trays. We recovered the tea bags after 122 days on 22 September 2017. Two tea bags buried in the swamp plots and one in an edge plot were unable to be recovered and were likely lost. Soil and plant roots were removed from the tea bags prior to oven-drying at $70^{\circ} \mathrm{C}$ for $48 \mathrm{~h}$.

The initial mass and final oven-dry mass were used to measure the mass loss over the burial period and to determine the decomposition rate constant $(k)$ and the stabilization factor (S) (Keuskamp et al. 2013). The stabilization of litter depends on environmental factors and results in the deviation of the actual decomposed fraction from the chemically labile fraction. This deviation is referred to as $S$, which represents an inhibiting effect of environmental conditions on the decomposition of the labile fraction (Keuskamp et al. 2013).
$S$ is calculated using the following formula:

$$
S=1-\frac{a_{\mathrm{g}}}{H_{\mathrm{g}}}
$$

where $a_{\mathrm{g}}$ is the decomposable fraction of green tea and $H_{\mathrm{g}}$ is the hydrolyzable fraction of green tea. Parameters $a_{\mathrm{g}}$ and $H_{\mathrm{g}}$ were derived from Keuskamp et al. (2013).

$k$ is calculated using the following exponential decay function:

$$
\text { (2) } \quad \mathrm{M}(t)=a_{\mathrm{r}} \mathrm{e}^{-k t}+\left(1-a_{\mathrm{r}}\right)
$$

where $M(t)$ is the mass of the substrate after incubation time $t, a_{\mathrm{r}}$ is the decomposable fraction of rooibos tea, and $1-a_{\mathrm{r}}$ is the recalcitrant fraction of rooibos tea.

$a_{\mathrm{r}}$ is calculated from the hydrolyzable fraction of rooibos tea $\left(H_{\mathrm{r}}\right)$, which is derived from Keuskamp et al. (2013), and $S$ using the following formula:

$$
a_{\mathrm{r}}=H_{\mathrm{r}}(1-S)
$$

\section{Organic and mineral soil sampling and analysis}

Between 27 June and 6 July 2017, we collected three forest floor samples and three mineral soil samples within each upland plot and three organic soil cores from each edge and swamp plot. We collected all samples by randomly selecting locations within a grid of eight $2.5 \mathrm{~m} \times 5 \mathrm{~m}$ quadrangles in each plot. For each sample, we measured $\mathrm{pH}$ using a SoilStik Pro Meter directly from the soil or later within a week under field moist conditions in the lab. 


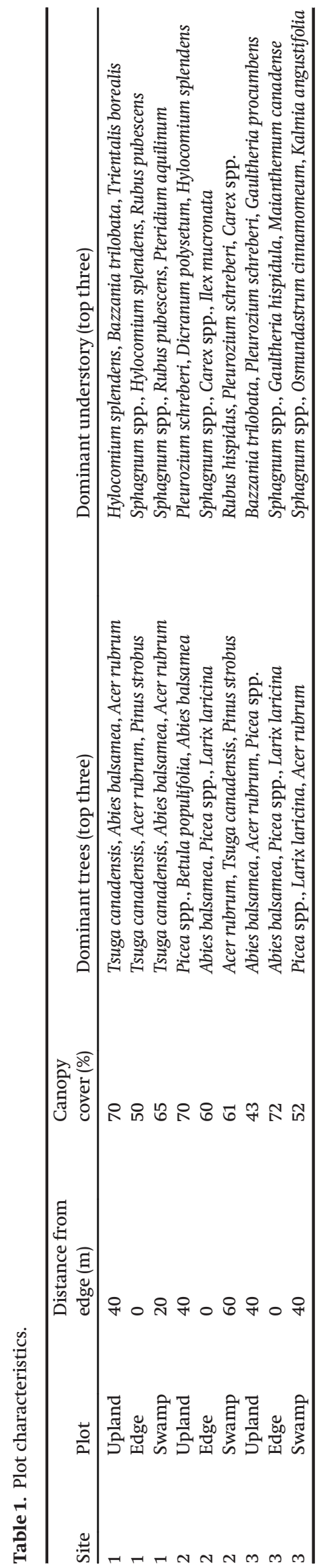

We employed different methods for collecting organic soil samples from each plot type. We collected some organic cores from the edge plots using polyvinyl chloride (PVC) pipes with a $3.8 \mathrm{~cm}$ diameter, whereas all swamp plot samples and some edge plot samples were collected using a metal pipe with a $5.2 \mathrm{~cm}$ diameter because PVC pipes were not strong enough to insert into the soil. All swamp and edge samples collected were placed in a bag and stored in a freezer at $-20^{\circ} \mathrm{C}$ until further analysis. In the upland, we extracted forest floor samples of approximately $17.5 \mathrm{~cm} \times 17.5 \mathrm{~cm}$ from the surface to the depth of the organicmineral interface using a shovel. We collected mineral soil samples from directly beneath the forest floor sample locations using a bulk density corer with a volume of $301.1 \mathrm{~cm}^{3}$. We then stored upland forest floor and mineral soil samples in a fridge at $4{ }^{\circ} \mathrm{C}$ until further analysis.

To analyze the moist organic soil cores from the edge and swamp, we took $2 \mathrm{~cm}$ subsamples every $20 \mathrm{~cm}$ along the core. We divided each upland plot forest floor sample into a grid of four cells, took a subsample from each quarter, and then combined the subsamples. All moist samples were weighed and then ovendried at $70^{\circ} \mathrm{C}$ for $24 \mathrm{~h}$ to determine the dry mass of the organic soil. We determined the mass of each moist mineral soil sample and then oven-dried the samples at $100{ }^{\circ} \mathrm{C}$ for $24 \mathrm{~h}$ to determine the dry mass. We calculated the water content and bulk density of each sample.

For organic soil samples, we removed a subsample of $10-20 \mathrm{~g}$ from the remainder of the oven-dried samples. Using a coffee grinder, we ground each subsample and then combined and mixed thoroughly on a per-plot basis. For mineral soil samples, we thoroughly mixed equal portions of the remaining mineral soil samples on a per-plot basis (Hamdan and Schmidt 2012; Turk et al. 2008). We sent the composite samples from each plot to the British Columbia Ministry of Environment Analytical Laboratory for analysis of total $\mathrm{C}$ and total $\mathrm{N}$. Total $\mathrm{C}$ and total $\mathrm{N}$ were determined by a dry combustion method using a Fisons NA-1500 elemental analyzer.

\section{Greenhouse gas measurement and analysis}

We measured GHG emissions using a nonsteady-state vented chamber technique. Collars made from $20 \mathrm{~cm}$ diameter PVC pipes cut to a height of $10 \mathrm{~cm}$ were installed into the soil at a depth of $5 \mathrm{~cm}$ prior to sampling ( 3 and 4 May 2017) and left in place for the duration of the sampling period. We installed four collars at each plot at locations determined randomly within 2.5 and $10 \mathrm{~m}$ from the centre of each plot. We collected GHG measurements on the same day each week from 9 May to 15 August 2017. We collected gas samples at approximately the same time each day and in the same order. However, our measurements were delayed by a few minutes up to $1 \mathrm{~h}$ between samples per plot and up to $2 \mathrm{~h}$ between sites because of travel time, introducing a potential source of bias. As vegetation grew in the collars, it was removed at the end of each set of measurements to ensure an unbroken seal between the collar and chamber for subsequent sampling dates.

On each sampling date, we placed a chamber $(20 \mathrm{~cm}$ diameter $\times$ $15 \mathrm{~cm}$ height) on each collar for $30 \mathrm{~min}$, during which time $20 \mathrm{~mL}$ gas samples were taken at $0,10,20$, and $30 \mathrm{~min}$ to determine chamber gas accumulation rates. For understanding environmental conditions under which soil biological activity and GHG production were occurring, we measured soil temperature and moisture adjacent to the flux chamber using a Decagon ProCheck handheld reader for each chamber location during the sampling period.

After all samples were collected, we transported the sample vials to the Dalhousie University Agricultural Campus Greenhouse Gas Lab for analysis. Gas samples were analyzed using gas chromatography (Varian Star 3800 Gas Chromatograph) using a system equipped with detectors to measure $\mathrm{CO}_{2}, \mathrm{CH}_{4}$, and $\mathrm{N}_{2} \mathrm{O}$ 
Table 2. Mean (standard deviation) litterfall properties ( $n=3$ plots each).

\begin{tabular}{|c|c|c|c|c|}
\hline Property & Upland & Edge & Swamp & $p$ \\
\hline \multicolumn{5}{|c|}{ Mass per unit area $\left(\mathrm{g} \cdot \mathrm{m}^{-2}\right)$} \\
\hline Spring & $71.53(29.00) \mathrm{a}$ & 34.19 (3.55) & $27.18(17.43) b$ & 0.079 \\
\hline Summer & $148.23(66.88)$ & $177.52(110.41)$ & $160.36(158.72)$ & 0.961 \\
\hline Autumn & $631.88(98.55)$ a & $514.28(105.24) \mathrm{ab}$ & $349.75(94.60) \mathrm{b}$ & 0.028 \\
\hline Study period & $851.63(144.48)$ & $725.99(179.21)$ & $537.29(196.25)$ & 0.290 \\
\hline \multicolumn{5}{|l|}{ C:N } \\
\hline Spring & $52(8.4)$ & $55(8.3)$ & $49(3.5)$ & 0.657 \\
\hline Summer & $67(6.1)$ & $70(8.9)$ & $54(17.1)$ & 0.373 \\
\hline Autumn & $109(17.2)$ & $109(27.8)$ & $86(42.6)$ & 0.364 \\
\hline Study period & $69(5.4)$ & $69(0.8)$ & $60(17.7)$ & 0.643 \\
\hline \multicolumn{5}{|l|}{ Concentration $\left(\mathrm{g} \cdot \mathrm{kg}^{-1}\right)$} \\
\hline Study period mean C & $534.08(1.98)$ & 533.49 (2.69) & $535.63(4.33)$ & 0.786 \\
\hline Study period mean $\mathrm{N}$ & $7.82(0.63)$ & $7.79(0.11)$ & $9.58(3.43)$ & 0.563 \\
\hline \multicolumn{5}{|l|}{ Content $\left(\mathrm{g} \cdot \mathrm{m}^{-2}\right)$} \\
\hline Spring total C & 38.24 (15.27) a & $18.33(2.07) \mathrm{ab}$ & $14.58(9.50) \mathrm{b}$ & 0.078 \\
\hline Summer total C & $203.57(224.33)$ & $161.63(106.04)$ & $206.75(151.64)$ & 0.792 \\
\hline Autumn total C & $229.34(134.72)$ a & $188.23(123.39) \mathrm{ab}$ & $115.38(98.75) \mathrm{b}$ & 0.094 \\
\hline Study period C & $537.73(108.44)$ & 397.73 (125.59) & $327.51(118.21)$ & 0.278 \\
\hline Spring total $\mathrm{N}$ & $14.37(23.52)$ & $6.89(11.33)$ & $8.60(14.58)$ & 0.402 \\
\hline Summer total $\mathrm{N}$ & $3.28(3.85)$ & $2.24(1.29)$ & $4.05(2.65)$ & 0.611 \\
\hline Autumn total $\mathrm{N}$ & $2.26(1.48)$ & $1.86(1.24)$ & $2.18(2.59)$ & 0.907 \\
\hline Study period N & $5.85(1.02)$ & $3.77(0.30)$ & $5.90(5.58)$ & 0.661 \\
\hline
\end{tabular}

Note: Values in boldface type indicate a significant difference of $p<0.10$. Letters designate significant differences among upland, edge, and swamp at $p<0.10$.

(Burton 2008). Daily flux values of $\mathrm{CO}_{2}, \mathrm{CH}_{4}$, and $\mathrm{N}_{2} \mathrm{O}$ over time were calculated using a linear trend according to Burton et al. (2008). We corrected for temperature using the ideal gas law and assumed pressure to be atmospheric because the chamber was vented. All flux values were retained in the data set and can be found in Appendix A. Cumulative GHG emissions $\left(\mathrm{g} \cdot \mathrm{m}^{-2}\right.$ ) over the monitoring period (May-August) were calculated by integrating daily flux values over time by interpolation between measurement dates using the trapezoidal rule. The experimental design was intended to measure differences between treatments rather than produce an estimate of the absolute magnitude of emissions and does not consider diurnal fluctuations.

When calculating $\mathrm{CO}_{2}$ equivalent sustained global warming potential, we multiplied $\mathrm{CH}_{4}$ and $\mathrm{N}_{2} \mathrm{O}$ fluxes by 45 and 270 , respectively (100-year time horizon; Neubauer and Megonigal 2015). We calculated total output associated with $\mathrm{CO}_{2}$ and $\mathrm{CH}_{4}$ emissions by using $\mathrm{C}$ fractions of the $\mathrm{CO}_{2}$ equivalent $\left(\mathrm{CO}_{2 e q}-\mathrm{C}\right)$.

\section{Carbon mass balance}

We calculated the $\mathrm{C}$ mass balance during the growing season accounting for $C$ input via litterfall and $C$ output via GHG emissions in the swamp plots using the following formula:

$$
\mathrm{C}_{\text {mass balance }}=\left(\mathrm{CF} \times \text { total } \mathrm{C}_{\text {litterfall }}\right)-\mathrm{CO}_{2 \text { eq. }}-\mathrm{C}
$$

where $\mathrm{CF}$ is a correction factor that represents the GHG emissions collection period divided by the litterfall collection period in days, and $\mathrm{CO}_{2 \text { eq. }}-\mathrm{C}$ represents total $\mathrm{C}$ output as $\mathrm{CO}_{2}$ and $\mathrm{CH}_{4}$. To account for a scenario of doubling soil GHG emissions due to climate change, based on a doubling wetland $C$ loss predicted by Clair et al. (2002), we recalculated total $C_{\text {mass balance }}$ using eq. 4 but with multiplying total $C_{\mathrm{GHG}}$ emissions by a factor of 2 .

\section{Statistical analysis}

We analyzed differences in litterfall, decomposition, soil, and GHG properties among the three plot types (upland, edge, and swamp) using IBM SPSS version 26 statistical software. We applied a
Table 3. Mean (standard deviation) decomposition parameters $(n=3$ plots each).

\begin{tabular}{lllll}
\hline Parameter & Upland & Edge & Swamp & $p$ \\
\hline Stabilization factor $(S)$ & $0.22(0.06)$ & $0.13(0.10)$ & $0.14(0.25)$ & 0.320 \\
Decomposition rate $(k)$ & $0.014(0.002)$ & $0.012(0.004)$ & $0.011(0.005)$ & 0.379 \\
\hline
\end{tabular}

mixed model with plot type (upland, edge, and swamp) as the fixed factor and the site (sites 1, 2, and 3) as the random factor, followed by the Tukey multiple comparison test if significant. An $\alpha$ level of 0.10 was used for all analyses because of a small sample size used and soil spatial heterogeneity of variables over space.

Organic soil and organic and mineral soil mass per unit area (bulk density multiplied by depth), temperature, moisture, $\mathrm{pH}$, total $\mathrm{C}$, total $\mathrm{N}$, and $\mathrm{C}: \mathrm{N}$ ratio were analyzed using the mixed model. Because there were no swamp mineral soil samples collected, an independent Student's $t$ test was used to compare means of the forested upland and edge plots. Unlike upland mineral soil samples, edge mineral soil samples were not analyzed for total C, so total $C$ values were estimated rather than analyzed by multiplying edge plot organic matter fraction of the mineral soil by the ratio of upland plot organic matter to total C.

Differences in litterfall mass, total $\mathrm{C}$, total $\mathrm{N}$, and $\mathrm{C}: \mathrm{N}$ ratio were analyzed for each season, as well as for the sum of all seasons, using the mixed model. The litter decomposition variables analyzed for differences were the decomposition rate $(k)$ and the stabilization factor $(S)$ using the mixed model. Cumulative GHG emissions derived from the integrated values at each collar, along with mean temperature and moisture content (\% volumetric) measured during the GHG study period, were also analyzed with the mixed model.

\section{Results}

Total litterfall over the entire study period was not significantly different among upland forest, edge, and swamp (Table 2). 
Table 4. Mean (standard deviation) organic soil and mineral soil properties ( $n=3$ plots each).

\begin{tabular}{|c|c|c|c|c|}
\hline Property & Upland & Edge & Swamp & $p$ \\
\hline Organic soil pH & $4.25(0.47)$ & $4.73(0.66)$ & $4.47(0.41)$ & 0.268 \\
\hline Mineral soil pH & $4.15(0.10)$ & $4.99(0.23)$ & NA & 0.010 \\
\hline Organic soil volumetric moisture $\left(\mathrm{mL} \mathrm{H}_{2} \mathrm{O} \cdot \mathrm{cm}^{-3}\right)$ & $0.05(0.02) \mathrm{a}$ & $0.22(0.11) \mathrm{b}$ & $0.25(0.11) \mathrm{b}$ & 0.006 \\
\hline Mineral soil volumetric moisture $\left(\mathrm{mL} \mathrm{H}_{2} \mathrm{O} \cdot \mathrm{cm}^{-3}\right)$ & $0.14(0.04)$ & $0.68(0.16)$ & NA & 0.010 \\
\hline Organic soil gravimetric moisture $\left(\mathrm{g} \mathrm{H}_{2} \mathrm{O} \cdot \mathrm{g}^{-1}\right.$ soil) & $0.43(0.01) \mathrm{a}$ & $0.77(0.14) \mathrm{b}$ & $0.86(0.03) \mathrm{c}$ & 0.005 \\
\hline Mineral soil gravimetric moisture $\left(\mathrm{g} \mathrm{H}_{2} \mathrm{O} \cdot \mathrm{g}^{-1}\right.$ soil $)$ & $0.19(0.10)$ & $0.28(0.01)$ & NA & 0.294 \\
\hline $\mathrm{C}: \mathrm{N}$ & $30(4.5)$ & $36(5.7)$ & $35(4.5)$ & 0.501 \\
\hline \multicolumn{5}{|l|}{ Concentration $\left(\mathrm{g} \cdot \mathrm{kg}^{-1}\right)$} \\
\hline Organic soil total C & $481.98(80.19)$ & $510.80(3.08)$ & $538.89(58.12)$ & 0.410 \\
\hline Mineral soil total C & $92.13(38.56)$ & $24.92(12.78)$ & NA & 0.107 \\
\hline Organic soil total $\mathrm{N}$ & $12.48(2.60)$ & $14.90(1.91)$ & $15.26(1.14)$ & 0.369 \\
\hline Mineral soil total $\mathrm{N}$ & $3.04(1.22)$ & NA & NA & \\
\hline \multicolumn{5}{|l|}{ Content $\left(\mathrm{g} \cdot \mathrm{m}^{-2}\right)$} \\
\hline Organic soil mass per unit area & $6982(2261)$ a & $12766(1711) a b$ & $38589(40788) b$ & 0.028 \\
\hline Mineral soil mass per unit area & $47884(11713)$ & 55942 (14 577) & NA & 0.538 \\
\hline Organic and mineral soil mass per unit area & 54865 (19 974) a & $38160(32603)$ a & $38589(40788)$ a & 0.421 \\
\hline Organic soil total C & $3456(1639)$ a & $6507(376) \mathrm{a}$ & $31061(2792) b$ & 0.002 \\
\hline Mineral soil total C & $4173(1358)$ & $1301(351)$ & NA & 0.068 \\
\hline Organic and mineral soil total C & $7629(1537)$ a & $7374(1151)$ a & $31061(2792) \mathrm{b}$ & 0.003 \\
\hline Organic soil total $\mathrm{N}$ & $91(47) \mathrm{a}$ & $189(13) \mathrm{a}$ & $822(14) b$ & 0.001 \\
\hline Mineral soil total $\mathrm{N}$ & $136(33)$ & NA & NA & \\
\hline Organic and mineral soil total $\mathrm{N}$ & $227(56)$ a & $189(13) \mathrm{a}$ & $822(14) \mathrm{b}$ & 0.001 \\
\hline
\end{tabular}

Table 5. Mean (standard deviation) soil greenhouse gas (GHG) emission properties ( $n=3$ plots each).

\begin{tabular}{lllll}
\hline Property & Upland & Edge & Swamp & $p$ \\
\hline Environmental parameters & & & & \\
Soil moisture $(\%$ volumetric) & $28.29(5.77) \mathrm{a}$ & $54.13(16.22) \mathrm{b}$ & $74.33(10.14) \mathrm{c}$ & $\mathbf{0 . 0 1 3}$ \\
Soil temperature $\left({ }^{\circ} \mathrm{C}\right)$ & $21.94(1.85)$ & $21.32(1.49)$ & $21.53(1.70)$ & 0.455 \\
& & & & \\
Cumulative emissions $\left(\mathrm{g} \cdot \mathrm{m}^{-2}\right)$ & & & & \\
$\mathrm{CO}_{2}$ & $161.17(34.68) \mathrm{a}$ & $134.73(71.60) \mathrm{a}$ & $84.94(42.70) \mathrm{b}$ & $\mathbf{0 . 0 6 7}$ \\
$\mathrm{CH}_{4}$ & $-0.05(0.02)$ & $1.71(3.37)$ & $3.14(4.98)$ & 0.307 \\
$\mathrm{~N}_{2} \mathrm{O}$ & $-0.001(0.00)$ & $0.00(0.00)$ & $0.00(0.01)$ & 0.321 \\
$\mathrm{CH}_{4}-\mathrm{CO}_{2 \text { eq. }}$ & $-2.03(0.96)$ & $77.14(151.49)$ & $141.44(224.00)$ & 0.307 \\
$\mathrm{~N}_{2} \mathrm{O}-\mathrm{CO}_{2 \text { eq. }}$ & $-0.02(1.11)$ & $-0.19(0.47)$ & $0.64(2.05)$ & 0.449 \\
$\mathrm{CO}_{2 \text { eq }}-\mathrm{C}$ & $43.40(9.53)$ & $57.78(41.35)$ & $61.74(66.80)$ & 0.763 \\
\hline
\end{tabular}

Note: Values in boldface type indicate a significant difference of $p<0.10$. Letters designate significant differences among upland, edge, and swamp at $p<0.10$. Soil moisture and temperature are weekly means over the GHG measurement period (9 May - 15 August 2017).

Significantly more litter fell in the upland plots than in the swamp plots in spring and autumn, but litter amounts were not significantly different among plot types for summer. The mean $\mathrm{C}: \mathrm{N}$ ratio, total $\mathrm{C}$, and total $\mathrm{N}$ were not significantly different among plot types, except for greater mean total $\mathrm{C}$ content in the upland during the spring and autumn seasons $(p<0.10)$. Although the swamp plot had the lowest stabilization factor and decomposition rate compared with the other plot types (Table 3), these were not significantly different from values for the upland and edge.

Organic soil properties of volumetric and gravimetric moisture content and mass per unit area were significantly greater in the swamp than in upland plots (Table 4). Both total C and total $\mathrm{N}$ content of the organic soil were significantly greater in the swamp than in the upland and edge. Mineral soil was collected only in the upland and edge plots because there was no mineral soil present in the soil cores from the swamp. The mineral soil properties of $\mathrm{pH}$, volumetric moisture content, and total $\mathrm{N}$ content were significantly greater in the edge than in upland plots, whereas total C content was significantly greater in the upland than in edge plots.

When organic and mineral soil data were combined, there was significantly more total $\mathrm{C}$ and total $\mathrm{N}$ content in the swamp than in the upland and edge (Table 4). The C:N ratio was not significantly different among plot types.

Mean $\mathrm{CO}_{2}$ emissions were significantly different among plot types, with greater $\mathrm{CO}_{2}$ emissions in the upland, whereas $\mathrm{CH}_{4}$ did not significantly differ among plot types (Table 5). Mean $\mathrm{N}_{2} \mathrm{O}$ 
emissions were not significantly different from $0.00 \mathrm{~g} \cdot \mathrm{m}^{-2}$ among plot types.

Treed swamp growing season $\mathrm{C}_{\text {mass balance }}$ showed that these sites are currently acting as a $\mathrm{C}$ sink, with $92.46 \mathrm{~g} \mathrm{C} \cdot \mathrm{m}^{-2}$ sequestered over the study period (May-August). Under a doubling of GHG emissions due to climate change scenario, $\mathrm{C}_{\text {mass balance indi- }}$ cated that these sites would still act as a $C$ sink, but sequestration would be reduced to $30.72 \mathrm{~g} \mathrm{C} \cdot \mathrm{m}^{-2}$ over a period of time corresponding to the GHG emissions study period.

\section{Discussion}

Litterfall from trees represents an input source of C into treed swamp ecosystems, and similar to upland forests, we found that treed swamps received large supplies of $C$ input through litterfall. The similarity in litterfall among the upland, edge, and swamp plots may be due to the similar proportion of canopy cover. The swamps may also have received litter input from the adjacent upland forests, resulting in a similarity in litterfall amounts between the uplands and swamps. Palik et al. (2006) collected litterfall within $1 \mathrm{~m}$ of forested wetland margins in Minnesota (United States) and found that litter was dominated by upland tree species.

We found the treed swamps to have higher litter inputs $\left(537.29 \mathrm{~g} \cdot \mathrm{m}^{-2}\right)$ than forested wetlands in other studies, which may be due to the type of tree species. Mitsch et al. (1991) studied forested wetlands in western Kentucky (United States), where they found mean litter inputs of $420 \mathrm{~g} \cdot \mathrm{m}^{-2} \cdot \mathrm{year}^{-1}$ for a seasonally flooded wetland, $136 \mathrm{~g} \cdot \mathrm{m}^{-2} \cdot$ year $^{-1}$ for a semipermanently flooded wetland, and $253 \mathrm{~g} \cdot \mathrm{m}^{-2} \cdot$ year $^{-1}$ for a permanently flooded wetland. Although the seasonally flooded forested wetland studied by Mitsch et al. (1991) may be the most similar to the treed swamps in our study, its tree species composition was broad-leaved deciduous rather than mixed forest. In another type of forested wetland, a coastal freshwater forested wetland dominated by Taxodium distichum (L.) Rich. in South Carolina (United States), Liu et al. (2017) reported annual litterfall to be $470 \mathrm{~g} \cdot \mathrm{m}^{-2} \cdot$ year $^{-1}$.

Higher tree litter inputs into treed swamps in our study, compared with other studies, may also be due to stand age. Younger forest stands can have less tree litter input than mature forest stands because of an open canopy. Palik et al. (2001) found that tree litter inputs averaged about $40 \mathrm{~g} \cdot \mathrm{m}^{-2} \cdot \mathrm{year}^{-1}$ in youngest stands in Minnesota seasonal ponds, increasing exponentially to $300 \mathrm{~g} \cdot \mathrm{m}^{-2} \cdot$ year $^{-1}$ with stand age. Understory litterfall may be greater with an open canopy but would still be greater in older forest stands (Tashe and Schmidt 2001). According to Megonigal and Day (1988) as referenced by Trettin and Jurgensen (2002), coniferous swamps have higher litterfall $\left(678-758 \mathrm{~g} \cdot \mathrm{m}^{-2} \cdot \mathrm{year}^{-1}\right)$ than measured in our study.

Environmental conditions that enhance litter decomposition include near-neutral $\mathrm{pH}$, sufficient soil moisture (60\%-75\%), and warm temperatures $\left(30-40^{\circ} \mathrm{C}\right)$ (Prescott 2010). The lack of significant difference in the decomposition rate and stabilization factor between upland and swamp was surprising, as wetlands are expected to have slower decomposition and higher stabilization due to anaerobic conditions. Nevertheless, our findings are in agreement with those of Moore et al. (2005), who found relatively small differences in litter decomposition between well-drained upland forests and nearby wetlands. Our findings that decomposition did not significantly vary between plot types may be explained by the similarity of $\mathrm{pH}$ and temperature between swamp and upland because $\mathrm{pH}$ (Rousk et al. 2009) and temperature (Pietikäinen et al. 2005) influence the soil microbial community to decompose litter.

Alternatively, these findings may be explained by high C:N ratios in upland forest and in swamp litter and soils. The availability of $\mathrm{N}$ can affect the decomposition rate by limiting the growth rate of microbial decomposers (Reddy and DeLaune
2008). Microbes require a C:N ratio of 20-30:1 in their food; if this ratio is greater, soil microbes scavenge the soil to obtain $\mathrm{N}$, and competition among microbes impacts $\mathrm{N}$ availability to plants. Decomposition can therefore be delayed if $\mathrm{N}$ availability in decomposing plant matter and soils is low. The high C: $\mathrm{N}$ ratio (greater than 30:1) of the upland litterfall may have led to delayed litter decomposition comparable to that of the swamps.

The type of method for measuring decomposition of litter may, however, limit results. The TBI, which we used to measure litter decomposition, may not be sensitive enough to detect differences in decomposition between the upland and swamp soils of our study. Macdonald et al. (2018) observed no significant differences in decomposition when comparing natural, restored, and extracted peatlands and suggested that the TBI is not easily comparable to traditional litterbag methods for measuring decomposition.

Soil moisture is a key factor affecting microbial activity and decomposition (Moyano et al. 2013). Swamp plots were found to have significantly greater moisture content than uplands, but decomposition rates were not significantly higher in the uplands than in swamps. Drought conditions can limit decomposition because declining soil moisture can decrease microbial activity. Upland plots had significantly lower soil moisture content, with volumetric moisture content as low as $10.13 \%$ in August and ranging up to $27.03 \%$ in July for summer months, possibly limiting decomposition. Prescott et al. (2004) reported that low moisture limits decomposition in forests, which may explain why decomposition rates were not higher in the uplands than in treed swamps in our study.

Drying-wetting cycles can also alter litter decomposition. Water depth fluctuated in the swamps during the decomposition period, with greater flooding in spring (100\% volumetric moisture content in flooded sites) and near-dry conditions in summer (as low as $43.45 \%$ volumetric moisture content at site 2 in July). Zhu and Cheng (2013) found that severe drying-wetting reduced plant biomass and decomposition of sunflower (Helianthus annuus L.) and soybean (Glycine max (L.) Merr.) plants. The changes in wet and dry conditions of the swamps may have provided suitable conditions for greater mass loss and hence faster decomposition rates than if they were permanently wet.

The pools of organic $C$ in soils result from the balance between inputs and outputs of $C$ over a relatively long period of time. Substantially more soil organic content accumulated in the swamps than in upland forests. Although there was not a significant difference in organic matter inputs from litterfall between swamps and upland forest soils, we found that upland forests stored significantly less $C$ than the swamps, which could be because of lower $\mathrm{CO}_{2}$ respiration in the swamps (Tables 4 and 5). Swamp soils had more than four times accumulated $C$ content compared with the adjacent upland forest soils, which is in agreement with the results of other studies of wetland ecosystems (e.g., Bernal and Mitsch 2008). This significant difference between the upland forests and the treed swamps indicates that the swamps may be more important for storing $C$ than uplands, where local hydrologic conditions may allow more organic matter to accumulate. Bernal and Mitsch (2008) found that even though upland soils had high organic matter inputs from trees and shrubs, the wetlands they studied in Ohio (United States) and Costa Rica had about 10 times more soil $C$ than their adjacent upland soils.

The treed swamps we studied had no apparent surface water connection for water supply, but rather were occasionally flooded during the year with drier periods in the summer. The hydrologic isolation of these swamps may be suitable for storing organic matter for longer periods of time than swamps with a regular water supply. For example, Bernal and Mitsch (2008) measured and compared the soil $C$ pools of different wetland types (riverine flow-through, slow-flowing slough, and isolated forested wetlands) and found significantly greater C pools but lower productivity in the isolated forested wetlands than other 
wetland types. The hydrological flux through wetland soils plays an important role affecting DOC flux, in that isolated wetlands may have reduced DOC output than if connected hydrologically to other systems (Hosen et al. 2018).

Total $\mathrm{C}$ soil emissions represented net positive $\mathrm{C}$ fluxes in all plot types. We found the swamps to emit similar $\mathrm{CH}_{4}$ fluxes as the edge and upland plots. Fluxes of $\mathrm{CO}_{2}$ were greater in the uplands than in the swamps, although decomposition rates were similar. A reason for the higher $\mathrm{CO}_{2}$ emitted from the uplands may be higher autotrophic root respiration or macrofauna predation and degradation of microorganisms (Kuzyakov 2006).

Like the treed swamp, the edge and upland forests also represent roles as $C$ sinks with large inputs of $C$ via litterfall. However, total soil C pools were smaller for the edge and upland than for the treed swamps. For the study period, we found edge plots to have intermediate values of $C$ inputs via litterfall and outputs via GHGs between those of the upland forests and treed swamps. If the swamp environment becomes drier with increasing temperatures and changes in precipitation due to climate change, the edge may also become more similar in condition to the upland forest environment, emitting greater quantities of GHGs. Higher temperature can increase GHG production and alter the degree of soil moisture content in wetlands. Over a 9-month period, Koh et al. (2009) found that the highest $\mathrm{CO}_{2}$ emissions occurred in a nonflooded upland forest in which high $\mathrm{CO}_{2}$ emission rates were correlated with relatively low soil moisture content.

Overall, rates of $\mathrm{CO}_{2}$ and $\mathrm{CH}_{4}$ flux from treed swamps in our study were lower than fluxes from wetlands reported in previous studies in southwestern Nova Scotia. Dalva et al. $(2001)$ measured higher $\mathrm{CO}_{2}$ and $\mathrm{CH}_{4}$ emissions in 1995 and 1996, but over a slightly longer monitoring period (mid-May-November). Mean $\mathrm{CO}_{2}$ emissions were $5.1 \mathrm{~g} \cdot \mathrm{m}^{-2} \cdot \mathrm{day}^{-1}\left(1863 \mathrm{~g} \cdot \mathrm{m}^{-2} \cdot \mathrm{year}^{-1}\right)$ in 1995 and $3.2 \mathrm{~g} \cdot \mathrm{m}^{-2} \cdot \mathrm{day}^{-1}\left(1169 \mathrm{~g} \cdot \mathrm{m}^{-2} \cdot \mathrm{year}^{-1}\right)$ in 1996 , and $\mathrm{CH}_{4}$ emissions were $43 \mathrm{mg} \cdot \mathrm{m}^{-2} \cdot \mathrm{day}^{-1}\left(16 \mathrm{~g} \cdot \mathrm{m}^{-2} \cdot \mathrm{year}^{-1}\right)$ in 1995 and $20 \mathrm{mg} \cdot \mathrm{m}^{-2} \cdot$ day $^{-1}$ $\left(7.3 \mathrm{~g} \cdot \mathrm{m}^{-2} \cdot\right.$ year $\left.^{-1}\right)$ in 1996. Clair et al. (2002) reported lower mean yearly $\mathrm{CH}_{4}$ emissions from 1992 to $1998\left(2.59 \mathrm{~g} \cdot \mathrm{m}^{-2}\right)$ than our study, but higher mean yearly $\mathrm{CO}_{2}$ emissions $\left(210.59 \mathrm{~g} \cdot \mathrm{m}^{-2}\right)$.

Our $\mathrm{CO}_{2}$ and $\mathrm{CH}_{4}$ measurements were also lower than measurements recorded by Koh et al. (2009) in a spring-fed forested wetland in Mississippi (United States), where $\mathrm{CO}_{2}$ and $\mathrm{CH}_{4}$ emissions were $350 \mathrm{mg} \cdot \mathrm{m}^{-2} \cdot \mathrm{h}^{-1}\left(3068 \mathrm{~g} \cdot \mathrm{m}^{-2} \cdot \mathrm{year}^{-1}\right)$ and $5.85 \mathrm{mg} \cdot \mathrm{m}^{-2} \cdot \mathrm{h}^{-1}$ $\left(51.2 \mathrm{~g} \cdot \mathrm{m}^{-2} \cdot\right.$ year $\left.^{-1}\right)$, respectively. Fluxes measured in our study may be lower because our monitoring period was shorter, from late spring and summer, so measurements during autumn or winter would have resulted in higher overall emissions. In a temperate peat swamp in southern Ontario (Canada), Davidson et al. (2019) reported higher $\mathrm{CO}_{2}$ emissions ranging from 2.8 to $11.8 \mathrm{~g} \mathrm{C} \cdot \mathrm{m}^{-2}$. day $^{-1}(1023-$ $4310 \mathrm{~g} \mathrm{C}^{-2} \mathrm{~m}^{-2} \cdot$ year $^{-1}$ ), but low $\mathrm{CH}_{4}$ emissions that fluctuated around $0 \mathrm{mg} \cdot \mathrm{m}^{-2} \cdot \mathrm{day}^{-1}$.

Although the treed swamps of our study emit $\mathrm{CO}_{2}$ and $\mathrm{CH}_{4}$ to the atmosphere, the influx of litterfall is greater, representing $92.46 \mathrm{~g} \mathrm{C} \cdot \mathrm{m}^{-2}$ sequestered during the growing season, representing $343 \mathrm{~g} \mathrm{C} \cdot \mathrm{m}^{-2} \cdot \mathrm{year}^{-1}$. Our $\mathrm{C}$ sequestration estimate is at the high end of $C$ sequestration rates estimated by Gallant et al. (2020) based on 2017 summer measurements in Nova Scotia of various wetland types, which ranged between 62 and $345 \mathrm{~g} \mathrm{C} \cdot \mathrm{m}^{-2} \cdot \mathrm{year}^{-1}$. Compared with estimates reported by Mitsch et al. (2013), our C sequestration estimate is higher than those of temperate peatlands $\left(10-46 \mathrm{~g} \mathrm{C}^{-2} \mathrm{~m}^{-2} \cdot \mathrm{year}^{-1}\right)$ and temperate coastal wetlands $\left(140-270 \mathrm{~g} \mathrm{C}^{-\mathrm{m}^{-2}} \cdot \mathrm{year}^{-1}\right)$.

Based on a scenario of doubling GHG emissions due to climate change, we estimated that $C$ sequestration in soil of the treed swamps would be reduced by a factor of about 3 (from $92.46 \mathrm{~g} \mathrm{C} \cdot \mathrm{m}^{-2}$ to $30.72 \mathrm{~g} \mathrm{C} \cdot \mathrm{m}^{-2}$ ). Our findings imply that $\mathrm{C}$ inputs through litterfall exceed $C$ outputs through GHG emissions of the treed swamps. In contrast, Clair et al. (2002) predicted that a poor fen in Kejimkujik National Park and National Historic Site may be converted from a passive $C$ storage area to an active $C$ source based on a doubled $C$ loss scenario over the next 50 years due to drier summer conditions. Drier periods will result in a lowering of the water table and thus an increase in $\mathrm{CO}_{2}$ production, which will not favour the maintenance of peat depth. Although the mean $C$ mass of the treed swamps $\left(31061 \mathrm{~g} \cdot \mathrm{m}^{-2}\right)$ in our study is similar to that estimated by Clair et al. (2002) $\left(40000 \mathrm{~g} \cdot \mathrm{m}^{-2}\right)$, they studied fen wetlands dominated by Sphagnum spp. lacking large mature trees.

Despite a reduction in $C$ sequestration with doubled $C$ losses, litterfall inputs would still exceed GHG outputs, resulting in net positive $C$ sequestration. In a changing climate in which rates of GHG production have the potential to accelerate because of rising temperatures (Davidson and Janssens 2006), the soils of treed swamps may still be able to maintain their role as a $\mathrm{C}$ sink.

Our $\mathrm{C}$ balance is an estimate based on litterfall and GHG emissions as $\mathrm{CO}_{2}$ and $\mathrm{CH}_{4}$, but it is limited by not accounting for tree biomass as a source of $\mathrm{C}$ input and considers GHG emissions during only spring and summer seasons. Soil respiration and litter decomposition may continue during winter months and reduce our $\mathrm{C}$ sequestration estimate. Biomass, however, if included, would increase the $\mathrm{C}$ input of our measurement. For future studies, we recommend considering trees more explicitly in C fluxes, as trees grow more slowly in swamps than in uplands because of waterlogged soil. Although we expected DOC to be low because of hydrologic isolation, DOC can contribute as a C output, which we did not include in our estimate. Root respiration is a potential contributor to $\mathrm{CO}_{2}$ emissions in the chamber measurements, but this was difficult to minimize because of the abundance of trees and tree roots at our study sites. The relative GHG emissions relied upon daily measurements, which do not consider diurnal fluctuations and therefore may not provide an accurate estimate of total emissions. Our estimate is also based on GHG emissions from soil and therefore does not include emissions from vegetation. Tree stems may potentially act as a conduit for $\mathrm{CH}_{4}$ emissions (Barba et al. 2019), which would not be captured in our estimate.

The assumption of doubled GHG emissions that we used to assess whether the swamps of our study will remain a $C$ sink with climate change is a simple scenario that does not consider potentially declining $\mathrm{CH}_{4}$ emissions by methanotrophs if the swamps become drier (Oremland and Culbertson 1992). Forest productivity may also be affected, depending on changes in seasonality and moisture availability (McMahon et al. 2010). A change in forest productivity will therefore impact the litterfall and GHG exchange.

\section{Conclusions}

We demonstrated that treed swamps of southwestern Nova Scotia can store larger quantities of soil organic $C$ in the soil and have litter inputs with greater $C$ than adjacent upland forests. Though the swamps are sources of $\mathrm{C}$ emissions through soil GHGs, they received a greater amount of $C$ input by way of litterfall. Growing season C input exceeds C output via soil GHG emissions by a factor of about 2.5. This highlights the ecological importance of temperate treed swamps as unique ecosystems. The tree and tall shrub cover of treed swamps provides high $C$ inputs through the forest litterfall that is not characteristic of other wetland types. Temperate treed swamps may be resilient to climate change because they can serve as a C sink despite a scenario of doubling GHG emissions. Our findings support conservation efforts to preserve treed swamps as a measure to mitigate climate change.

\section{Acknowledgements}

Funding for this research was provided by the Atlantic Ecosystems Initiatives (AEI) funding program and a Natural Sciences and Engineering Research Council of Canada (NSERC) undergraduate research scholarship. We thank the Dalhousie University Agricultural Campus Greenhouse Gas Lab for training on how to properly collect gas samples using their chamber equipment and for analyzing our gas samples. 


\section{References}

Barba, J., Bradford, M.A., Brewer, P.E., Bruhn, D., Covey, K., Haren, J., et al. 2019. Methane emissions from tree stems: a new frontier in the global carbon cycle. New Phytol. 222(1): 18-28. doi:10.1111/nph.15582. PMID:30394559.

Bernal, B., and Mitsch, W.J. 2008. A comparison of soil carbon pools and profiles in wetlands in Costa Rica and Ohio. Ecol. Eng. 34(4): 311-323. doi:10.1016/j.ecoleng.2008.09.005.

Bhatti, J.S., Errington, R.C., Bauer, I.E., and Hurdle, P.A. 2006. Carbon stock trends along forested peatland margins in central Saskatchewan. Can. J. Soil Sci. 86(Special Issue): 321-333. doi:10.4141/S05-085.

Burton, D. 2008. Soil greenhouse gas flux measurement toolkit. Dalhousie University Agricultural College, Agricultural Greenhouse Gas Mitigation Program, Truro, N.S

Burton, D.L., Zebarth, B.J., Gillam, K.M., and MacLeod, J.M. 2008. Effect of split application of fertilizer nitrogen on $\mathrm{N}_{2} \mathrm{O}$ emissions from potatoes. Can. J. Soil Sci. 88(2): 229-239. doi:10.4141/CJSS06007.

Campbell, C., Vitt, D.H., Halsey, L.A., Campbell, I.D., Thormann, M.N., and Bayley, S.E. 2000. Net primary production and standing biomass in northern continental wetlands. Can. For. Serv. Inf. Rep. NOR-X-369. Natural Resources Canada, Canadian Forest Service, Northern Forestry Center, Edmonton, Alta. Available from https://cfs.nrcan.gc.ca/publications?id= 11646 [accessed 5 May 2020].

Clair, T.A., Arp, P., Moore, T.R., Dalva, M., and Meng, F.R. 2002. Gaseous carbon dioxide and methane, as well as dissolved organic carbon losses from a small temperate wetland under a changing climate. Environ. Pollut. 116: S143-S148. doi:10.1016/S0269-7491(01)00267-6. PMID:11833902.

Dalva, M., Moore, T.R., Arp, P., and Clair, T.A. 2001. Methane and soil and plant community respiration from wetlands, Kejimkujik National Park, Nova Scotia: measurements, predictions, and climate change. J. Geophys. Res. 106(D3): 2955-2962. doi:10.1029/2000JD900500.

Davidson, E.A., and Janssens, I.A. 2006. Temperature sensitivity of soil carbon decomposition and feedbacks to climate change. Nature, 440(7081): 165-173. doi:10.1038/nature04514. PMID:16525463.

Davidson, S.J., Strack, M., Bourbonniere, R.A., and Waddington, J.M. 2019. Controls on soil carbon dioxide and methane fluxes from a peat swamp vary by hydrogeomorphic setting. Ecohydrology, 12(8): e2162. doi:10.1002/ eco.2162.

Flanagan, L.B., and Syed, K.H. 2011. Stimulation of both photosynthesis and respiration in response to warmer and drier conditions in a boreal peatland ecosystem. Global Change Biol. 17(7): 2271-2287. doi:10.1111/j.1365-2486.2010. 02378.x.

Gallant, K., Withey, P., Risk, D., van Kooten, G.C., and Spafford, L. 2020. Measurement and economic valuation of carbon sequestration in Nova Scotian wetlands. Ecol. Econ. 171: 106619. doi:10.1016/j.ecolecon.2020.106619.

Gorham, E. 1991. Northern peatlands: role in the carbon cycle and probable responses to climatic warming. Ecol. Appl. 1(2): 182-195. doi:10.2307/1941811.

Government of Canada. 2017. Historical data. Kejimkujik 1. Available from http://climate.weather.gc.ca/historical_data/search_historic_data_e.html [accessed 20 October 2018].

Hamdan, K., and Schmidt, M.G. 2012. The influence of bigleaf maple on chemical properties of throughfall, stemflow, and forest floor in coniferous forest in the Pacific Northwest. Can. J. For. Res. 42(5): 868-878. doi:10.1139/x2012-042.

Hartmann, D.L., Tank, A.M.G.K., Rusticucci, M., Alexander, L.V., Brönnimann, S., Charabi, Y., et al. 2013. Observations: atmosphere and surface. Climate Change 2013: The Physical Science Basis. In Contribution of Working Group I to the Fifth Assessment Report of the Intergovernmental Panel on Climate Change. Edited by T.F. Stocker, D. Qin, G.-K. Plattner, M. Tignor, S.K. Allen, J. Boschung, et al. Cambridge University Press, Cambridge, U.K. Available from http://www.ipcc.ch/report/ar5/wg1/ [accessed 18 November 2017].

Hogg, E.H., Lieffers, V.J., and Wein, R.W. 1992. Potential carbon losses from peat profiles: effects of temperature, drought cycles, and fire. Ecol. Appl. 2(3): 298-306. doi:10.2307/1941863.

Hosen, J.D., Armstrong, A.C., and Palmer, M.A. 2018. Dissolved organic matter variations in coastal plain wetland watersheds: the integrated role of hydrological connectivity, land use, and seasonality. Hydrol. Process. 32(11): 1664-1681. doi:10.1002/hyp.11519.

Keuskamp, J.A., Dingemans, B.J.J., Lehtinen, T., Sarneel, J.M., and Hefting, M.M. 2013. Tea Bag Index: a novel approach to collect uniform decomposition data across ecosystems. Methods Ecol. Evol. 4(11): 1070-1075. doi:10.1111/2041210X.12097.

Koh, H.-S., Ochs, C.A., and Yu, K. 2009. Hydrologic gradient and vegetation controls on $\mathrm{CH}_{4}$ and $\mathrm{CO}_{2}$ fluxes in a spring-fed forested wetland. Hydrobiologia, 630(1): 271-286. doi:10.1007/s10750-009-9821-x.

Kuzyakov, Y. 2006. Sources of $\mathrm{CO}_{2}$ efflux from soil and review of partitioning methods. Soil Biol. Biochem. 38(3): 425-448. doi:10.1016/j.soilbio.2005.08.020.

Lal, R. 2008. Carbon sequestration. Philos. Trans. R. Soc. B, Biol. Sci. 363(1492): 815-830. doi:10.1098/rstb.2007.2185. PMID:17761468.

Limpens, J., Berendse, F., Blodau, C., Canadell, J.G., Freeman, C., Holden, J., et al. 2008. Peatlands and the carbon cycle: from local processes to global implications - a synthesis. Biogeosciences, 5(5): 1475-1491. doi:10.5194/ bg-5-1475-2008.
Liu, X., Conner, J.H., Song, B., and Jayakaran, A.D. 2017. Forest composition and growth in a freshwater forested wetland community across a salinity gradient in South Carolina, USA. For. Ecol. Manage. 389: 211-219. doi:10.1016/j.foreco.2016.12.022.

MacDonald, E., Brummell, M.E., Bieniada, A., Elliott, J., Engering, A., Gauthier, T.-L., et al. 2018. Using the Tea Bag Index to characterize decomposition rates in restored peatlands. Boreal Environ. Res. 23: 221-235.

McCrady, R.L., and Jokela, E.J. 1998. Canopy dynamics, light interception, and radiation use efficiency of selected loblolly pine families. For. Sci. 44(1): 64-72. doi:10.1093/forestscience/44.1.64.

McMahon, S., Parker, G., Miller, D., and Schlesinger, W. 2010. Evidence for a recent increase in forest growth. Proc. Natl. Acad. Sci. U.S.A. 107(8): 36113615. doi:10.1073/pnas.0912376107. PMID:20133710.

Megonigal, J.P., and Day, F.P., Jr. 1988. Organic matter dynamics in four seasonally flooded forest communities of the dismal swamp. Am. J. Bot. 75(9): 1334-1343. doi:10.1002/j.1537-2197.1988.tb14194.x.

Miao, G., Noormets, A., Domec, J.-C., Fuentes, M., Trettin, C.C., Sun, G., et al. 2017. Hydrology and microtopography control carbon dynamics in wetlands: implications in partitioning ecosystem respiration in a coastal plain forested wetland. Agric. For. Meteorol. 247: 343-355. doi:10.1016/j. agrformet.2017.08.022

Middleton, B.A. 2020. Trends of litter decomposition and soil organic matter stocks across forested swamp environments of the southeastern US. PLoS One, 15(1): e0226998. doi:10.1371/journal.pone.0226998. PMID:31899783.

Mitsch, W.J., and Hernandez, M.E. 2013. Landscape and climate change threats to wetlands of North and Central America. Aquat. Sci. 75(1): 133149. doi:10.1007/s00027-012-0262-7.

Mitsch, W.J., Taylor, J.R., and Benson, K.B. 1991. Estimating primary productivity of forested wetland communities in different hydrologic landscapes. Landsc. Ecol. 5(2): 75-92. doi:10.1007/BF00124662.

Mitsch, W.J., Bernal, B., Nahlik, A.M., Mander, Ü., Zhang, L., Anderson, C.J., et al. 2013. Wetlands, carbon, and climate change. Landsc. Ecol. 28(4): 583-597. doi:10.1007/s10980-012-9758-8.

Moomaw, W.R., Chmura, G.L., Davies, G.T., Finlayson, C.M., Middleton, B.A., Natali, S.M., et al. 2018. Wetlands in a changing climate: science, policy and management. Wetlands, 38: 183-205. doi:10.1007/s13157-018-1023-8.

Moore, T.R., Trofymow, J.A., Siltanen, M., Prescott, C., and Group, C.W. 2005. Patterns of decomposition and carbon, nitrogen, and phosphorus dynamics of litter in upland forest and peatland sites in central Canada. Can. J. For. Res. 35(1): 133-142. doi:10.1139/X04-149.

Moyano, F.E., Manzoni, S., and Chenu, C. 2013. Responses of soil heterotrophic respiration to moisture availability: an exploration of processes and models. Soil Biol. Biochem. 59: 72-85. doi:10.1016/j.soilbio.2013.01.002.

National Wetlands Working Group. 1997. The Canadian Wetland Classification System. 2nd ed. Edited by B.G. Warner and C.D.A. Rubec. Wetlands Research Centre, University of Waterloo, Waterloo, Ont. Available from http:/www. wetlandpolicy.ca/canadian-wetland-classification-system/ [accessed 15 March 2018].

Neily, P.D., Quigley, E., Benjamin, L., Stewart, B., and Duke, T. 2005. Ecological land classification for Nova Scotia (Report DNR 2005). Nova Scotia Department of Natural Resources, Renewable Resources Branch, NS. Available from https://novascotia.ca/natr/forestry/ecological/ecolandclass.asp [accessed 9 June 2017].

Neily, P.D., Basquill, S., Quigley, E., and Keys, K. 2017. Ecological Land Classification for Nova Scotia (Report for 2017-13). Province of Nova Scotia Department of Natural Resources, N.S. Available from https://novascotia. ca/natr/forestry/ecological/ecolandclass.asp [accessed 20 October 2018].

Neubauer, S.C., and Megonigal, J.P. 2015. Moving beyond global warming potentials to quantify the climatic role of ecosystems. Ecosystems, 18(6): 1000-1013. doi:10.1007/s10021-015-9879-4.

Nova Scotia Department of Lands and Forestry. 2013. Forest Inventory Geographic Information Systems. UTM Zone 20N NAD83. Province of Nova Scotia. Available from https://novascotia.ca/natr/forestry/gis/forest-inventory. asp [accessed 17 October 2020].

Oremland, R., and Culbertson, C. 1992. Importance of methane-oxidizing bacteria in the methane budget as revealed by the use of a specific inhibitor. Nature, 356(6368): 421-423. doi:10.1038/356421a0.

Palik, B., Batzer, D.P., Buech, R., Nichols, D., Cease, K., Egeland, L., and Streblow, D.E. 2001. Seasonal pond characteristics across a chronosequence of adjacent forest ages in northern Minnesota, USA. Wetlands, 21(4): 532-542. doi:10.1672/0277-5212(2001)021[0532:SPCAAC]2.0.CO;2.

Palik, B., Batzer, D.P., and Kern, C. 2006. Upland forest linkages to seasonal wetlands: litter flux, processing, and food quality. Ecosystems, 9(1): 142151. doi:10.1007/s10021-005-0010-0.

Pietikäinen, J., Pettersson, M., and Bååth, E. 2005. Comparison of temperature effects on soil respiration and bacterial and fungal growth rates. FEMS Microbiol. Ecol. 52(1): 49-58. doi:10.1016/j.femsec.2004.10.002. PMID:16329892.

Prescott, C.E. 2010. Litter decomposition: what controls it and how can we alter it to sequester more carbon in forest soils? Biogeochemistry, 101(1-3): 133-149. doi:10.1007/s10533-010-9439-0.

Prescott, C.E., Blevins, L.L., and Staley, C. 2004. Litter decomposition in British Columbia forests: controlling factors and in fluences of forestry activities. B.C. J. Ecosyst. Manage. 5(2): 44-57.

Reddy, R., and DeLaune, R.D. 2008. Biogeochemistry of wetlands: science and applications. Taylor \& Francis Group, Boca Raton, Fla. 
Rousk, J., Brookes, P.C., and $\mathrm{Ba}^{3} \mathrm{a}^{3}$ th, E. 2009. Contrasting soil $\mathrm{pH}$ effects on fungal and bacterial growth suggest functional redundancy in carbon mineralization. Appl. Environ. Microbiol. 75(6): 1589-1596. doi:10.1128/AEM. 02775-08. PMID:19151179.

Rowe, J.S. 1972. Forest regions of Canada. Publication No. 1300. Department of Environment, Canadian Forestry Service, Ottawa, Ont. Available from http://www.cfs.nrcan.gc.ca/publications/?id=24040 [accessed 14 June 2017].

Sabau, J., Schmidt, M.G., and Krzi, M. 2010. The impact of black cottonwood on soil fertility in coastal western hemlock forest. For. Ecol. Manage. 260(8): 1350-1358. doi:10.1016/j.foreco.2010.07.029.

Schmidt, M.W.I., Torn, M.S., Abiven, S., Dittmar, T., Guggenberger, G., Janssens, I.A., et al. 2011. Persistence of soil organic matter as an ecosystem property. Nature, 478(7367): 49-56. doi:10.1038/nature10386. PMID: 21979045.

Tashe, C.N., and Schmidt, M.G. 2001. The impact of vine maple on site fertility of coastal temperate forests. For. Ecol. Manage. 147(2-3): 263-279. doi:10.1016/S0378-1127(00)00468-0.

Trettin, C.C., and Jurgensen, M.F. 2002. Carbon cycling in wetland forest soils. In The potential of U.S. forest soils to sequester carbon and mitigate the greenhouse effect. Edited by J.M. Kimble, R. Lal, R. Birdsey, and L.S. Heath. CRC Press, Boca Raton, Fla. pp. 311-331.
Turk, T.D., Schmidt, M.G., and Roberts, N.J. 2008. The influence of bigleaf maple on forest floor and mineral soil properties in a coniferous forest in coastal British Columbia. For. Ecol. Manage. 255(5-6): 1874-1882. doi:10.1016/j. foreco.2007.12.016

Vogt, K.A., Grier, C.C., and Vogt, D.J. 1986. Production, turnover, and nutrient dynamics of above- and belowground detritus of world forests. Adv. Ecol. Res. 15: 303-377. doi:10.1016/S0065-2504(08)60122-1.

Whiting, G.J., and Chanton, J.P. 2001. Greenhouse carbon balance of wetlands: methane emission versus carbon sequestration. Tellus B, 53(5): 521-528. doi:10.3402/tellusb.v53i5.16628.

Zhang, H., Yuan, W., Dong, W., and Liu, S. 2014. Seasonal patterns of litterfall in forest ecosystem worldwide. Ecol. Complex. 20: 240-247. doi:10.1016/j. ecocom.2014.01.003.

Zhu, B., and Cheng, W. 2013. Impacts of drying-wetting cycles on rhizosphere respiration and soil organic matter decomposition. Soil Biol. Biochem. 63: 89-96. doi:10.1016/j.soilbio.2013.03.027.

\section{Appendix A: $\mathrm{CO}_{2}, \mathrm{CH}_{4}$, and $\mathrm{N}_{2} \mathrm{O}$ chamber flux measurements}

Table A1. Means of $\mathrm{CO}_{2}$ fluxes $\left(\mu \mathrm{g} \cdot \mathrm{m}^{-2} \cdot \mathrm{s}^{-1}\right)$ from upland, edge, and swamp plots $(n=4$ chambers).

\begin{tabular}{|c|c|c|c|c|c|c|c|c|c|}
\hline \multirow[b]{2}{*}{ Sampling date } & \multicolumn{3}{|c|}{ Upland } & \multicolumn{3}{|l|}{ Edge } & \multicolumn{3}{|c|}{ Swamp } \\
\hline & Site 1 & Site 2 & Site 3 & Site 1 & Site 2 & Site 3 & Site 1 & Site 2 & Site 3 \\
\hline 2 May 2017 & 22.80 & 7.04 & 11.42 & 6.65 & 0.60 & 9.81 & 4.35 & 11.12 & 1.02 \\
\hline 16 Мay 2017 & 17.78 & 6.67 & 12.47 & 5.36 & 9.68 & 12.03 & 4.93 & 7.42 & 12.09 \\
\hline 23 May 2017 & 12.97 & 12.65 & 12.88 & 9.23 & 7.89 & 6.44 & 6.27 & 6.25 & 2.38 \\
\hline 30 May 2017 & 14.97 & 13.20 & 13.81 & 9.39 & 13.90 & 12.04 & 5.49 & 14.31 & 4.38 \\
\hline 6 June 2017 & 12.47 & 12.04 & 10.78 & 11.90 & 9.35 & 8.49 & 4.04 & 9.61 & 4.67 \\
\hline 13 June 2017 & 23.64 & 10.82 & 22.36 & 16.66 & 26.78 & 15.50 & 6.02 & 23.21 & 8.17 \\
\hline 20 June 2017 & 30.53 & 16.01 & 21.52 & 4.46 & 4.66 & 20.39 & 4.82 & 11.44 & 6.10 \\
\hline 27 June 2017 & 14.93 & 25.32 & 19.35 & 30.85 & 20.09 & 21.61 & 5.94 & 19.22 & 7.79 \\
\hline 5 July 2017 & 22.95 & 25.92 & 23.37 & 29.33 & 26.39 & 21.34 & 4.07 & 20.24 & 10.82 \\
\hline 11 July 2017 & 16.24 & 23.48 & 20.61 & 29.84 & 20.76 & 16.88 & 6.26 & 17.30 & 9.30 \\
\hline 18 July 2017 & 12.93 & 20.02 & 18.10 & 40.47 & 17.25 & 9.49 & 8.89 & 30.05 & 9.08 \\
\hline 25 July 2017 & 17.45 & 14.09 & 10.49 & 6.62 & 8.67 & 17.90 & 7.02 & 15.82 & 8.31 \\
\hline 1 August 2017 & 18.62 & 37.19 & 22.41 & 35.07 & 22.97 & 11.51 & 11.58 & 38.85 & 22.57 \\
\hline 8 August 2017 & 47.74 & 19.78 & 14.05 & 11.82 & 16.42 & 12.93 & 9.82 & 3.62 & 4.47 \\
\hline 15 August 2017 & 60.56 & 32.09 & 24.43 & 10.26 & 26.47 & 21.66 & 8.92 & 7.84 & 12.42 \\
\hline
\end{tabular}

Table A2. Means of $\mathrm{CH}_{4}$ fluxes $\left(\mathrm{ng} \cdot \mathrm{m}^{-2} \cdot \mathrm{s}^{-1}\right)$ from upland, edge, and swamp plots $(n=4$ chambers).

\begin{tabular}{|c|c|c|c|c|c|c|c|c|c|}
\hline \multirow[b]{2}{*}{ Sampling date } & \multicolumn{3}{|c|}{ Upland } & \multicolumn{3}{|l|}{ Edge } & \multicolumn{3}{|l|}{ Swamp } \\
\hline & Site 1 & Site 2 & Site 3 & Site 1 & Site 2 & Site 3 & Site 1 & Site 2 & Site 3 \\
\hline 2 May 2017 & -4.88 & -1.02 & -3.36 & -1.14 & 0.65 & -0.97 & 1.68 & 0.96 & 8.65 \\
\hline 16 Мay 2017 & -3.69 & -1.52 & -3.55 & 0.36 & 11.27 & 0.15 & 0.48 & 4.54 & 24.28 \\
\hline 23 May 2017 & -3.50 & -2.58 & -2.99 & 1.58 & 18.38 & -0.96 & 2.28 & 11.13 & 5.65 \\
\hline 30 May 2017 & -5.79 & -2.33 & -4.04 & 0.49 & 21.25 & 0.07 & 4.51 & 47.08 & 46.84 \\
\hline 6 June 2017 & -4.62 & -2.06 & -4.19 & 69.37 & 130.9 & -0.59 & 35.81 & 61.13 & 19.32 \\
\hline 13 June 2017 & -7.67 & -1.37 & -5.90 & 8.81 & 213.9 & -1.26 & 43.42 & 115.0 & 38.74 \\
\hline 20 June 2017 & -5.67 & -1.40 & -7.89 & 4.59 & -105.9 & 2.93 & 104.3 & 127.1 & 1936 \\
\hline 27 June 2017 & -5.86 & -16.70 & -12.98 & 508.9 & 1616 & 19.50 & 162.3 & 593.4 & 3357 \\
\hline 5 July 2017 & -6.10 & -3.13 & -5.03 & 450.4 & 901.6 & 15.52 & 12.53 & 669.5 & 1834 \\
\hline 11 July 2017 & -5.93 & -8.15 & -4.65 & 181.5 & 2151 & 4.59 & 82.76 & 1871 & 40.49 \\
\hline 18 July 2017 & -5.47 & -7.63 & -4.65 & 202.5 & 836.8 & 4.38 & 183.8 & 3177 & 179.9 \\
\hline 25 July 2017 & -5.98 & -2.88 & -4.82 & -25.48 & -446.1 & -4.46 & -402.2 & 267.7 & 53.38 \\
\hline 1 August 2017 & -7.41 & -6.63 & -8.03 & 13.72 & 1169 & -0.88 & -1415.8 & 693.5 & 901.9 \\
\hline 8 August 2017 & -10.19 & -2.18 & -1.86 & -28.22 & 72.98 & 1.83 & 52.38 & 16.71 & 6.79 \\
\hline 15 August 2017 & -12.60 & -4.76 & -6.52 & 7.20 & 986.2 & -0.67 & 348.13 & 98.07 & 811.0 \\
\hline
\end{tabular}


Table A3. Means of $\mathrm{N}_{2} \mathrm{O}$ fluxes $\left(\mathrm{ng} \cdot \mathrm{m}^{-2} \cdot \mathrm{s}^{-1}\right)$ from upland, edge, and swamp plots ( $n=4$ chambers).

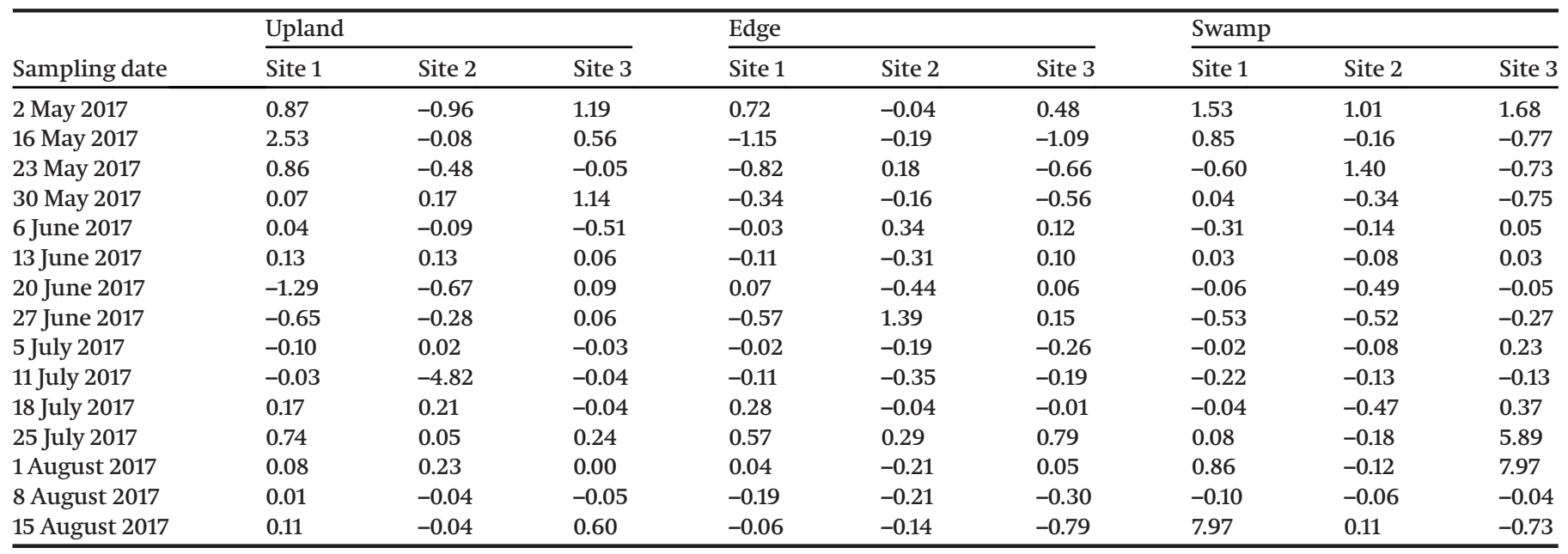


Copyright of Canadian Journal of Forest Research is the property of Canadian Science Publishing and its content may not be copied or emailed to multiple sites or posted to a listserv without the copyright holder's express written permission. However, users may print, download, or email articles for individual use. 